\title{
LIBERALE POLITIEK EN SPORTBOIKOTTE
}

"The majority interpretes Liberalism solely as that attitude towards race relations which is most opposed to the traditional outlook and policy of South Africa, as formulated and practised by the Voortrekkers" (Hoernlé, 1945, p 103).

In hierdie artikel word ingegaan op die ontwikkeling van die liberale gedagte in die rassepolitiek van Suid-Afrika en hoe dit verband hou met sport-politieke konflikte en sportboikotte. Talle feite en gebeure dui pertinent daarop dat liberalisme ' $n$ belangrike motivering was vir 'n groot verskeidenheid aksies wat vorme van gemengde of veelrassige sport op die oog gehad het. Dit het sy hoogtepunt bereik in pogings om alle vorme van apartheisport te boikot en sodoende Suid-Afrika van internasionale sport te isoleer tot tyd en wyl veelrassige sport alhier sy inslag gevind het.

Naas kommunisme en swart Afrikanisme, het plaaslike liberaliste, asook van elders, 'n kritieke rol vervul om internasionale sportisolasie op Suid-Afrika af te dwing. Die primêre motief agter hierdie aksies was om blanke alleenbeheer in politiek en sport uit te daag deur situasies te skep wat moes lei na gemengde of veelrassige sport, en desnoods, ook politiek. Die sport moes meehelp om 'n bres in apartheid te slaan wat uiteindelik moes eindig in die verkrummeling van blanke oppergesag en die vernietiging van die bestaande stelsel. So formuleer John Dugdale, eertydse Britse Parlementslid en Minister van Koloniale Sake, hierdie oogmerk toe hy in 1958 as spreker optree by ' $n$ betoging teen Suid-Afrika se deelname aan die Statebondspele: "If we can break down the colour bar in sport, we will break down the whole barrier of Apartheid" (Rand Daily Mail), 9.7. 58).

Alle konfrontasies van apartheidsport was egter nie net polities gemotiveerd nie; humanitēre beweegredes het dikwels swaar geweeg. Daar was diegene wat opreg oortuig was dat die blanke Suid-Afrikaner met die louere van internasionale sport wegloop en dat die land se apartheidspolitiek hierdie toedrag van sake eenvoudig bestendig. Dis gesien as onbillik. Neigings tot diskriminasie teen swart sportmanne asook geringskatting van menslike waardigheid en kwaliteit is in die sport opgemerk, wat verset uitgelok het. Dis moeilik, en waarskynlik onmoontlik, om 'n heldere onderskeid te trek tussen politieke en humanitêre motiewe in die sportkonflik. Dié twee aksente vloei eenvoudig ineen. In hierdie monoloog word hoofsaaklik aandag gegee aan politieke aksente. 
Die liberale gedagte het in die Suid-Afrikaanse politiek op twee verhoudingsvlakke duidelik tot uiting gekom, dié tussen Afrikaner (Boer) en Engelstalige (Brit), en dié tussen blanke en nie-blanke. Toe sentimente tussen Boer en Brit hoog geloop het, is diegene met proBritse sentimente as liberaliste uitgekryt. Vandag het hierdie polarisasie getemper geraak en het blank/nie-blanke verhoudinge in die kalklig kom staan. Die graad van 'n persoon se poltieke liberaalheid word vandag grootliks bepaal deur die mate waarin hy veelrassigheid voorstaan of nie. Diegene met prointegrasiesentimente word as liberaliste geoormerk, terwyl diegene wat konsekwent staan op blanke dominansie en meerderwaardigheid die teenoorgestelde pool vorm, in Wimpie die Klerk-terme, die verkramptes. Wanneer in hierdie artikel oor die „liberale gedagte” geskryf word, val die klem hoofsaaklik op die strewe na veelrassigheid en algehele gelykberegtiging. Die terme „liberaal” en „,liberalisties”, so ook „liberales" en ,,liberaliste”, word af wisselend gebruik sonder dat 'n skerp onder skeid getrek word.

Karakterisiek van die liberalisme is sy geloof $i_{\Lambda}$ die goedheid van die mens en die strategie van die moment in die positiewe en blymoedige uiteinde van dit wat nagestreef word. Dit bring ' $n$ blye boodskap, hoop in stede van wanhoop, optimisme in stede van pessimisme, en verworpenheid. Die idee word geskep dat die liberalisme 'n aardse utopia nastreef, 'n geluksalige gemeenskap wat gebou is op agting en respek vir mekaar se vryhede en regte. Die klem val op die vryheisdgedagte en minder sterk op gesag en verantwoordelikheid. Verantwoordelikheid word beskou as 'n natuurlike uitvloeisel van die liberalisme, dit staan egter nie voorop nie. 'n Liberale gemeenskap veronderstel verdraagsaamheid of permissiwiteit, begrip en agting vir die waardigheid van andere. Die idee van 'n gesagstaat, op watter grondslag ook al, word summier verwerp as sou dit gevaar inhou vir individuele en ander vryhede. Die vryheidsgedagte, die groot klem op humanitêre waardes, die positivisme en optimisme - dit alles mak dit 'n verleidelik-aantreklike filosofie.

In sy oorspronklike vorm het die liberalisme uit die humanisme en rasionalisme van die $18 \mathrm{e}$ en $19 \mathrm{e}$ eeu ontwikkel. Hieruit het liberale ideale ontwikkel wat belangrike stukragte was agter die Franse Revolusie, die Industriële Revolusie, die Amerikaanse Vryheidsoorlog, die dekolonialisering van Afrika. in 'n groot mate ook die Anglo-Boere Oorlog van 1899 tot 1902 , en in resente tye die stryd in Ieriand en Suider-Afrika. In al hierdie konflikte was die strewe na vryheid, selfbeskikking, en gelykberegtiging die sentrale motief, ongeag uiteenlopende politieke stelsels. Liberale ideale is nie die alleenbesit van die Westerse kapitalistiese demokrasieë nie, dit vorm ook deel van die 
sosialisme en selfs van die kommunisme, teenstrydig soos dit mag klink.

Die liberalisme van die $19 \mathrm{e}$ eeu is ' $\mathrm{n}$ produk van blanke gemeenskappe van Europa. In die slagkreet van vryheid, gelykheid en broederskap stol die wese van die liberalisme. Die oorspronklike oogmerke van hierdie slagkreet was om klassestrukture en klasse-dominansies van daardie era te vernietig en 'n maatskappy tot stand te bring waar demokratiese regte van alle individue en groepe erken en gewaarborg word. Vryheid moes na die massas uitgebrei word, na die volk, en nie die alleenbesit van 'n klein elitegroep bly nie. Die aansprake op vryhede en regte was tussen eenderskleurige gemeenskappe, blankes. Europese liberalisme is later na ander lande, kontitinente en kulture oorgedra, na heterogene gemeenskappe met anderse kultuurhistoriese erfenisse. Die konsekwente implimentering van liberalistiese ideale het in sulke gemeenskappe probleme opgelewer daar dit op revolusie en geweld kon uitioop. In baie gevalle sou dit die vernietiging van bestaande ordes en stelsels beteken. Dis daarom te begryp dat liberalisme nie orals met ope arms ontvang is nie, ook hier in Suid-Afrika.

Nougesette liberales streef na 'n egalitariese gemeenskap waar eenderse regte en vryhede vir alle individue geld, ongeag verskille in godsdiens, ras, kleur, geletterdheid, of ekonomiese bedrewenheid. In die praktyk het so 'n benadering slegs op papier uitgewerk. Realiteite het die praktiese implementering van sulke ideale net nie altyd gewens gemaak nie. So was die Amerikaners as toegewyde kampvegters van die liberale idee, wat selfs die essensie van die liberale gedagte in hul grondwet verskans het, aanvanklik nie bereid om liberale ideale streng na die letter in hul eie veelrassige gemeenskap deur te trek nie, en het dit uiteindelik gelei tot die stryd om burgerregte wat in die vyftigerjare ontketen is en omstreeks 1968 'n hoogtepunt bereik het. Toe Brittanje oor die Kaapkolonie en later oor Suid-Afrika geregeer het, is probleme ervaar om liberale ideale na die letter in die praktyk deur te trek. Realiteite het hul gedwing tot 'n kompromie, tot afwatering. Die skreeuende inkonsekwentheid was dat Brittanje as uitgesproke kampvegter vān liberale ideale, self die grootste imperiale moondheid van alle tye was! Probleme in die toepassing van liberale ideale in veelrassige of veelkulturige gemeenskappe word tans ervaar in Israel, Oeganda, Indië, Brittanje, Holland, Ierland, en die Verenigde State van Amerika.

Die evolusie van liberalisme in Suid-Afrika word deur twee strominge gekenmerk : eerstens, aksente wat aansluiting vind by die filosofieë 
van die ou Kaapse Liberales met wortels in die $18 \mathrm{e}$ en $19 \mathrm{e}$ eeu; tweedens, kontemporêre opvattinge van radikale liberaliste wat sedert 1958 in die openbaar getree het en 'n klimaks in die vroeë sestigerjare bereik het. Radikale liberaliste, hoewel gering in getal, het ' $n$ buitengewoon belangrike invloed op die inisiëring en deurvoering van sportboikotte teen Suid-Afrika gehad, manipulasies wat vandag nog voortduur. Hierdie mense is daadgeoriënteer, dade wat verandering en selfs revolusie moes losruk. Hul doel was om volle veelrassigheid in Suid-Afrika tot stand te bring. Hulle was bereid om langs onkonstitusionele metodes verandering af te dwing, so lank die strewe na veelrassigheid verwesenlik kon word. Die ou Kaapse Liberales het ook eventuele veelrassigheid op die oog gehad, maar dit moes bereik word langs evolusionêre en konstitusionele weg. Hierin lê die groot.verskil.

\section{KAAPSE LIBERALISME : 1828 TOT 1958}

Die Suide word beskou as die bakermat van liberalisme in SuidAfrika. Gedurende die laaste drie dekades, egter, het Transvaal met Johannesburg aan die spits leidend in die liberale politiek geword. Johannesburg as toonaangewende sake- en nywerheidstad het vanweë sy kosmopolitiese en veelrassige samestelling sterker in die brandpunt van die rassekonflik kom staan as enige ander stad of gemeenskap in Suid-Afrika. Johannesburg met sy uitgesproke en uitdagende joernalistiek het uiteindelik die arsenaal van sowel die ou Kaapse Liberalisme as hedendaagse radikale liberalisme geword. Dis hier waar progressiewe politiek sy inslag gevind het. Die swaartepunt van Suid-Afrikaanse politieke liberalisme het na die nasionalistiese noorde verskuiwe waar tans die woeling en aksie is, waar na alle waarskynlikheid Suid-Afrika se toekomstige rasse- en volkerepatroon aan't ontplooie is.

\section{VOOR UNIEWORDING: $1828-1910$}

Deur die 19e eeu en die eerste helfte van die 20e eeu het die liberale gedagte 'n belangrike impak op rasseverhoudinge gehad. Die Britse owerheid het meegehelp om status aan liberale denke toe te ken. Sedert 1948 het daar verwydering gekom. Teen die end van die vyftigerjare het die liberaal-politieke vennootskap sodanig versleg dat aan liberalisme ' $n$ kommunistiese bysmaak toegeken is. Daar is aangevoer dat radikale liberales in hul dade om 'n veelrassige maatskappy tot stand te bring die sport het midde in hierdie stryd gestaan die oogmerke van die kommunisme help bevorder. Hierteen het liberales kras geprotesteer en die owerheid daarvan beskuldig dat 
hulle die argument bloot as 'n rookskerm gebruik om op outokratiese wyse indringende opposisie te onderdruk of uit te wis.

Britse liberalisme dateer terug tot die begin van die 19e eeu. Ordinansie 50 van 1828 bied 'n vergestalting hiervan. Dit het die emansipasie van Hottentotte en Kleurlinge verseël. In 1836 en 1842 word dit verder uitgebrei, en word die Parlement van die Kaapkolonie en van Natal in 1853 in ooreenstemming met die beginsels van sosiale gelykheid saamgestel. Aan nie-blankes wat 'n bepaalde beskawingstandaard bereik het, is stemreg en sosiale regte toegesê. Die Zuid-Afrikaanse Republiek van president Paul Kruger, egter, het die basiese gegedagte van ,apartheid" bly nastreef.

Die liberale ideale van die ou Kaapse skool was egter nie sonder kwalifikasie nie. Hoernlé (1939) formuleer dit so : "It is an ideal which we may not restrict in application to men of one race or creed, of one blood or culture, denying it to all men of other races and creeds, other bloods and cultures. This does not imply, that the liberal spirit must be blind to such differences and ignore them where they exist." Daar is besef dat algehele gelykheid net nie kan werk so lank daar enorme kultuur- en beskawingsverskille tussen rasse bestaan nie. Kultuur- en beskawingsverskille is dan ook aanvaar as maatstaf waarvolgens regte en vryhede aan nie-blankes toegegeken kon word. Eers wanneer aan 'n bepaalde standaard van beskaafdheid voldoen is, kon nie-blanke individue sulke voorregte deelagtig word. Daar is dus sprake van selektiwiteit, van diskriminasie teenoor diegene wat nie aan die standaard voldoen nie. Watter standaard? Die Westerse beskawing en dié van die blanke Anglo-Sakiese ras is as kanon of maatstaf geneem en verhef tot dié elite-kultuur wat dikteer in hoeverre die swart- of bruinman op liberale regte en vryhede kon aanspraak maak. Die implikasie hiervan is dat die nieblanke se kultuur en beskawing sonder meer as ondergeskik gesien is. Die kultuur van die swartman moes tot die van die witman of Westerling bekeer word. Die behoud van die Westerse beskawing is dan ook as hoogste doel gesien en nagestreef. Tog bevat hierdie motief ' $n$ eienaardige skisofrenie: as die behoud van die Westerse beskawing en kultuur die finale oogmerk van blanke dominansie was, dan is dit tog ook logies om te verwag dat die blanke uit sy pad sou gaan om die nie-blankes te verwesters. Dis egter nie gedoen nie; op die duur sou dit die blanke se oppergesag bedreig.

Liberales is van politieke oneerlikheid beskuldig. Aan die een kant wou hulle bly regeer; aan die ander kant het hul gewetes hul aangekla dat afgewyk word van beginsels van gelykheid, geregtigheid, en selfbeskikking. Hulle was wel bereid om toegewings te doen solank 
dit die magsposisie van die imperiale gesag nie wesenlik sou aantas nie. In der waarheid het dit op despotisme neergekom. Die uitspraak van Abraham Lincoln in 1854 is hier van toepassing:

"When the White man governs himself, that is self-government; but when he governs himself and also governs another man, that is more than self-government - that is despotism . . . . What I do say is that no man is good enough to govern another man without that other's consent."

In hierdie dilemma het die politiek van die Kaapse Liberales hul voor 1900 bevind.

\section{NA UNIEWORDING: $1910-1970$}

Met uniewording in 1910 het Kaapse Liberales aangedring op stemreg vir nie-blankes wat aan 'n bepaalde beskawingstandaard voldoen het. Horisontale sowel as vertikale sosiale en politieke mobiliteit moes aan hierdie mense gewaarborg word. Aan die minder beskaaf. des moes geleentheid gegun word om geleerdheid te bekom om daaideur groter vryhede en regte deelagtig te word. Vir so ' $n$ bedeling was Kaapland en Natal te vinde: Transvaal en die Oranje-Vrystaat het egter teenstand gebied. John X Merriman, eertydse Eerste Minister van Kaapland, verklaar dat "... no sympathy for the Boer cause (could) ever excuse any sort of departure form a liberal policy."

Invloedryke liberaliste omstreeks uniewording was: $J \mathrm{H}$ de Villiers, J W Sauer, Walter Stanford, John X Merriman, W P Schreiner,

Olive Schreiner, James Rose Innes, Jan $\mathrm{H}$ Hofmeyr, Alfred en Winnefred Hoernlé, en in mindere mate ook Generaals Louis Botha en Jan Smuts. John X. Merriman was die mees invloedryke voorstander van stemreg aan beskaafde nie-blankes. Boonop sou dit ook dien as 'n nuttige veiligheidsklep vir politieke en sosiale aspirasies, is aangevoer. Jan Hofmeyr het dié benadering gesteun as 'n daad wat onderlinge goeie gesindheid tussen rasse sou bevorder.

Om kommunikasie tussen rasse moontlik te maak was dit noodsaaklik dat 'n eenderse taal en kultuur nagestreef moes word. Verengelsing het onvermydelik geword. Lynreg hierteenoor was die standpunt van die Oranje-Vrystaat en dié van Transvaal soos vertolk deur Generaal J B M Hertzog, en later dr D F Malan. Maar ook Hertzog met sy oop sin vir realisme en billikheid sou later te "liberaal" word vir die nougesette nasionaliste van die noorde ... Gedurende die eerste dekade na uniewording is die kleurkwessie so ver moontlik buite die partypolitiek gehou. Dit was klaarblyklik die bedoeling van Botha en Smuts om die saak aan 'n meer bevoegde nageslag oor te laat. Die blanke minderheidsgroep het deur'n selfopge- 
legde voogdyskap gesag oor 'n nie-blanke meerderheidsgroep bly voer. Dit het oor die inisiatief en mag beskik om te beslis welke politieke, ekonomiese, sosiale, en ander regte die nie-blanke toekom. Blanke baasskap en dominansie het die essensie van die politiek na uniewording gebly.

Die nie-blanke is as politieke en sosiale ondergeskikte gesien. Dis bloot logies om te verwag dat sosiale afstand en afsondering ook in die sport moes voorkom. Reeds voor 1900 toe Kaapse Liberalisme in sy blom gestaan het, is sport op die basis van rasse-afsonderlikheid beoefen, blankes apart en nie-blankes apart. Hierdie gebruik het oor dekades die tradisionele geword. $\mathrm{Na} 1910$ is nasionale sportliggame gestig wat dan ook internasionale status verkry het. Engelstaliges het in die vroeë stadia die inisiatief geneem om sport hier te vestig en ook tegelyk te dikteer hoe die vraagstuk van rasseverhoudinge in die sport gehanteer moet word. Klubs, provinsies en nasionale liggame is op suiwere rassegrondslag georganiseer. Ope klubs was buite die kwessie. Weliswaar het enkele gevalle van gemengde sportmededinging voorgekom, maar dan het dit geskied op die basis van welwillendheidswedstryde. In boks, krieket, tennis, gholf en korfbal het sulke wedstryde voorgekom. In den brede, egter is die beginsel van afsonderlike sportbeoefening tot op internasionale vlak deurgetrek. Daar het geen regeringsgeformuleerde bepalings bestaan wat hierdie praktyk afgedwing het nie; dis deur konvensies en gewoontes gereguleer. Hierdie praktyk het voortgeduur tot na 1948.

In 1924 gaan die Nasionale Party in koalisie met die Arbeidersparty. Generaal J B M Hertzog se regering gee prominensie aan die rassekwessie en oorweeg in 1926 wetgewing wat duideliker riglyne moes neerlê om swart-wit-verhoudinge te reël. Hy ervaar probleme. Met die rassekwessie ' $n$ vername aksent van die verkiesingsveldtog, behaal Hertzog in 1929 'n oortuigende meerderheid en verbreek die vennootskap met die Arbeidersparty. Hy oorweeg strenger maatreëls om rasseverhoudinge te reël. Vanuit Afrikanergeledere het die teenkanting teen integrasionistiese neigings toegeneem en sou dit ook spoedige aanklank in die sport vind. Die All Balck-toer van 1929 is hierdeur geraak. George Nepia, donkerkleurige Maorispeler van wêreldfaam, was 'n seker keuse vir die span. Rugby-administrateurs het 'n lastige konfrontasie vroegtydig onderskep. Nepia het in NieuSeeland agtergebly en in 1937 weier Maori's om hul tradisionele wedstryd teen die Springbokke te speel. In 1939 kom die rassekwessie weer ter sprake toe 'n Kleurling-sokkerspan deur Brittanje wou gaan toer. Teen hierdie tyd was die grondslag vir apartheidsport reeds gelê. 
Dit was eers in 1939 dat die rassekwessie tot prioriteit nommer een in die politiek verhef is. Die Gesuiwerde Nasionale Party van dr D F Malan het in duidelike taal op apartheid aangedring. Hierna sou aparte ontwikkeling na vore tree as die téénstroming van die ideale van die Kaapse Liberales en sou dit in 1948 die deurslag gee aan die Nasionale Party se oorwinning by die stembus.

Die uitbreek van die Tweede Wêreldoorlog in 1939 bring 'n tydelike frontverandering in die liberale politiek. Die rassekwessie skuiwe tydelik na die agtergornd, en Suid-Afrika se toetrede tot die oorlog kom staan in die brandpunt. Liberales gee hul eenparige steun aan die oorlogpoging en kom in skerp verset teen patriotiese aksies van Afrikaners wat neutraal en onverskillig teenoor die oorlogpoging staan. Vir Afrikaners was dit duidelik dat die liberales meer pro-Brittanje in hul politieke sentimente was as voorstaanders van suiwer liberale beginsels.

In 1940 dring die oorlogpolitiek die sport binne. Vanuit die Oostelike Provinsie versprei dit na Transvaal en later na die Westelike Provinsie. Rugby word in diens van die oorlogspoging gestel toe daar besluit word om hekontvangste aan oorlogsliefdadigheid te skenk. Anti-oorlogsgesindes het hierdie pogings drasties beveg en oorlogge sindes daarvan beskuldig dat hulle politiek by sport insleep. So heftig word die struweling dat ' $n$ breuk in die Oostelike Provinsie en in die Westelike Provinsie se rugby-unies onaf wendbaar word. Transvaal het op nerf na 'n breuk afgeweer. Eers na beëindiging van die oorlog is die breuk weer geheel. Hierna sou die rassekwessie in sport na vore tree.

Voor 1948 het dit uiters selde gebeur dat liberales protes aangeteken het teen rasse-afsonderlikheid in sport. So ver bekend was Alfred Hoernlé (1939) die enigste een wat die heersende praktyk bevraagteken het. Hy merk op: „Liefs rassesegregasie in belang van rassedominansie as die kameraadksap wat sport oor rassegrense heen bied dit is die heersende houding" (pp $33-34$ ). Getrou aan die Britse tradisie, is die sport gesien as ' $n$ instituut wat buite die politiek staan. Die kentering kom eers met die uitgang van die veertigerjare toe Tafeltennis in openlike konfrontasie kom teen blanke alleenbeheer in Suid-Afrika se nasionale en internasionale sportverhoudinge. Die idee van blanke trustee- of voogdyskap is 'n uitvloeisel van die Volkerebond wat na die vrede van Versailles in 1919 tot stand gekom het. Die internasionale gemeenskap het vir byna drie dekades daarna bly aanvaar dat die nie-blanke van Suid-Afrika die „, heilige trust van die blanke beskawing" vorm. Hierdie beginsel is ook na die sport deurgetrek. Blankbeheerde nasionale sportliggame het as 
voogde van nie-blanke sport opgetree deur hierdie liggame op internasionale vlak te verteeriwoordig. Nie-blanke sportlui het geen direkte verteenwoordiging op nasionale liggame gehad nie, wat staan nog vir nasionale spanne in aanmerking kom.

In Suid-Afrika het „voogdyskap" drie interpretasies ontlok: permanente trusteeskap en gevolglike blanke dominansie - die beleid van die Verenigde Party; trusteeskap wat strewe na versnelde akkulturasie en verwestering wat uiteindelik moet lei tot veelrassige naasbestaan - die benadering van Kaapse Liberales soos tans voorgestaan deur die Progressiewe Party, en, derdens, trusteeskap wat die bevoogde nie-blankes moet voorberei vir uiteindelike soewereine onafhanklikheid i $e^{-\curvearrowleft}$ gebiede - die beleid van die Nasionale Party. Al drie hierdie aksenve het 'n duidelike neerslag in die sportpolitiek van sestig en sewentig gevind. Lees slegs die Parlementsverslae van die laaste dekade.

Met die uitgang van die veertigerjare was daar twee gebeurtenisse wat sterk rigtinggewend was vir die ontplooiing van liberale denke deur ' 50 en '60: die totstandkoming van die Verenigde Volkere-Organisasie in 1947 en die bewindsaanvaarding van die Nasionale Party in Mei 1948. Die VVO het aan die eise van liberales uit Suid-Afrika 'n breë maar gevoelige klankbord gegee. Hul kon hul op hierdie organisasie beroep en tegelyk krag put uit die sterk liberale rigting wat dit aangedui het. Die aanvaarding van die Universele Deklarasie van Fundamentele Menseregte op 10 Desember 1948 kan beskou word as 'n internasionale sege vir die liberalisme. Afgesien van politieke en sosiale regte, het dit ook 'n duidelike omskrywing gebied van regte wat in die sport geld.

Liberales in die Verenigde Pary het na 1948 gehoop dat die party uiteindelik sal liberaliseer en wegbreek van Generaal Smuts se beleid van blanke baasskap. Smuts het vasgeskop „Our policy has not been equal rights. It is an abstraction forced upon us by our opponents. We stand and have always stood for European supremacy in this country. We have said that we have a position of guardianship, of trusteeship, over the non-European peoples in the country, and we must carry out that trust in the true spirit of guardianship ... We have never been in favour of equal rights. We have always stood and we stand for social and residential separation in this country, and for the avoidance of all racial mixture." (Volksraad Debatte, Vol. 65, 21.9. '48/2905). Smuts het herhaaldelik bly weier om toe te gee aan linkervleuel wat aangedring het op groter toeskietlikheid in rasseverhoudinge. 
Die aanvang van die vyftigerjare het spanning en konflik gebring. In Junie 1952 word die Defiance Campaign georganiseer. Honderde nieblankes verbrand in die openbaar hul pasboekies om daardeur hul openlike afkeur te toon vir die regering se apartheidsmaatreëls. Vanuit Afrikaner en Engelstalige geledere kom sterk afkeur van hierdie aksies. Hierdie groep mense se steun wou die Verenigde Party ten alle koste behou, veral met die verkiesing van 15 April 1953 net om die draai. Daar is volhard met die beleid van. blanke baasskap en 'n mate van ekonomiese integrasie. Al in 1948 het Smuts verklaar: ,the native has been integrated into our economic system ... he is part and parcel of the whole which constitutes South African economic society ..." (Volksraad Debatte, Vol. 64, 16.7.'48/203). Hierby het Smuts bly staan.

Die Verenigde Party se kritiek teen apartheid was grootlik pragmaties van aard, teen die wyse of metode waarvolgens aparte ontwikkeling geimplementeer is. (Dieselfde pragmatisme het ook in die sportpolitiek na vore gekom). Die grondliggende verskil het gelê in die uiteinde van tuislandontwikkeling. Waar die Nasionale Party die eindpunt gesien het in soewereine onafhanklike state, het die Verenigde Party 'n federasie van state nagestreef. Die Verenigde Party het gevoel dat die nougesette en verreikende wetgewing wat die Nasionale Party sedert 1948 aangeneem het, nie nodig was nie. Dis gesien as te omvangryke ingrype in die individuele vryhede van burgers. Hul kritiek teen die regering was hoofsaaklik bepaal deur toestande in die land self, dit wil sê hoedanig wet en orde in stand gehou is, asook die omvang van oorsese kritiek, die wêreldmening.

In sy wese was die Verenigde Party van die vroeë vyftigerjare 'n gematigde konserwatiewe party. Dit het die inisiatief en vitaliteit van die Nasionale Party gemis. Engelstaliges wat die oorgrote aanhang van die party uitgemaak het, het grootliks gekom van 'n ryk middelklas, mense wat ' $n$ gemaksugtige lewe verkies het en min van die Afrikaner se agressiewe politieke passie besit het. Hul politieke entoesiasme was by uitstek toegespits op ekonomiese vooruitgang, op materiële stabiliteit, en natuurlik sport. Die Afrikaner weer was arm, het weining aandeel in die inisiatief aangaande die ekonomiese gehad. Hý sou die lastige wrywingspunte moes opvang wat integrasie sou bring. Die Engelstalige se kapitaal het hom verskans. Hy kon dus van. weë sy begunstigde ekonomiese posisie bekostig om liberaal te wees. Die Afrikaner nie. Daarom dat daar 'n sterker drif by die afrikaner was om inisiatief in die politiek te bekom en te behou. Dit het nie by die politiek geëindig nie. Dit was eweneens vir hom belangrik dat hy 
inisiatief moes verkry in die sport wat tot nog toe grootliks in die bestuurshande van Engelstaliges was. Dit alles het van hom 'n vitale mag in die politiek van die Nasionale Party gemaak.

Die Torch Commando, saamgestel uit blanke en nie-blanke oud-soldate, het by tye vitaliteit aan die Verenigde Party gegee en dit na 'n aspirerende opposisie laat lyk. So betoog hulle op 19 Mei 1951 voor die Parlement en bots met die polisie, ' $n$ insident wat groot emosionaliteit ontketen. In 1952 betoog hulle saam met Kleurling-bataljons teen die regering se besluit om die politieke regte van Kleurlinge in te trek. Die regering word van troubreuk teenoor die Kleurling beskuldig. Dis hoe ver hierdie beweging se liberalisme gegaan het. As stoere lede van die Verenigde Party het hulle solied by die tradisionele idee van paternalisme en blanke baasskap bly staan. Die Kleurling moes egter nader getrek word.

Saam met die Arbeidersparty en die Torch Commando stig die Verenigde Party op 16 April 1952 die United Democratic Front om groter steun te werf vir die 1953 verkiesing. Met die stigting van hierdie front is 'n deklarasie uitgereik waarin belangrike liberale ideale herbevestig is. Daar is opnuut nadruk gelê op die reg van vrye akademiese inrigtings, die gelykheid van die blanke rasse, eerbied vir die „rule of law”, respek vir die "heilige erfenis van die grondwet" en noodsaaklikheid om Suid-Afrika se posisie as geëerde lid van die internasionale gemeenskap weer in ere te herstel. Teenoor kleurverhoudinge het hulle egter konserwatief bly staan.

In 1952 kom daar ' $n$ belangrike wending in die liberale politiek. In aansluiting by die ideale van die Ou Kaapse Liberale skool, publiseer 'n groep liberaliste in die Oktober-uitgawe van Forum 'n verklaring waarin standpunt ingeneem word teen maatreëls wat die regering getref het om die Defiance Campaign, wat op 26 Junie van stapel gestuur is, in die kiem te smoor. Liberales soos Margaret Ballinger, W C Ballinger, Julius Lewin, Leo Marquard, Donald Molteno, Alan Paton, en andere verklaar dat as Suid-Afrika die steun van opgevoede en beskaafde nie-blankes wil verkry en behou, hy bereid moet wees om sosiale en politieke status aan hierdie mense te verseker. Daar word aangedring op „... . gelyke regte aan alle beskaafde mense, asook gelyke kanse aan alle manne en vroue om beskaafd te raak. „Hierdie verklaring het inderdaad 'n kentering in die liberale politiek ingelui wat uiteindelik verreikende konsekwensies vir die sport sou inhou.

Liberales binne die Verenigde Party het 'n identifiseerbare pressiegroep begin vorm. Op 8 Januarie 1952 organiseer 'n groep liberale 
akademici, professioneles, en politici die eerste samekoms van die South African Liberal Group. Die aandrang op die emansipasie van beskaafde nie-blankes vergroot. Op 26 Junie, die aanvangsdag van die Defiance Campaign, daag Patrick Duncan en vier ander radikale liberales die regering se apartheidswette uit. Hulle verkies om opgesluit te word. Vir liberales was dit 'n moeilike pil om te sluk. By vele, veral by Duncan, laat dit verbittering na.

Lede van die South African Liberal Group het simpatiek gestaan teenoor die aspirasies van die African National Congress (ANC), en in mindere mate ook teenoor dié van die kommunisties beheerde South African Indian Congress (SAIC). Hulle sou dit egter nie in die openbaar bekendmaak nie; vlak voor die 1953 verkiesing sou dit die Verenigde Party in verleentheid stel. Liberaliste uit hierdie groep was hoogsversigtig om openlike steun aan kommunistiese bedrywighede

te gee. Toe die kommunisties geinspireerde Congress of Democrats in November 1952 te Johannesburg gestig is om 'n heenkome te bied aan lede van die 1950 verbanne Kommunistiese Party, was Margaret Ballinger van die eerste liberales wat haar van hierdie verlengstuk van die kommunisme gedistansieer het. Eerstens wou hulle nie met kommuniste geassosieer word nie, en tweedens het hulle beswaar geopper teen die feit dat die Congress of Democrats ' $n$ suiwer blanke organisasie was, 'n parallel van die ANC en die SAIC Konsekwente liberales het ' $n$ veelrassige organisasie verkies bo die blanke Congress of Democrats.

Dit is betekenisvol dat lede dan die Congress of Democrates, die African National Congress, die S A Indian Congress, en later ook die South African Coloured People's Organization spontaan verkies het om hul organisasie op rassegrondslag te organiseer, lynreg in stryd met hul ideale vir 'n veelrassige maatskappy. Dieselfde verskynsel het hom ook in die sport afgespeel. Die sport van die Bantoe, die Indiër, en die Kleurling is in die dekades voor ' 50 eweneens op rassegrond slag georganiseer. Op aandrang van liberales en druk vanuit internasionale liggame is daar later besluit op oorkoepelende veelrassige sportorganisasies. Hierdie liggame sou poog om internasionale status te verkry deur die affiliasie van die blankbeheerde nasionale liggame te betwis as onverteenwoordigend van die Suid-Afrikaanse sportgemeenskap.

Teen einde 1952 het liberales besef dat dit tyd geword het om hul aksies te koördineer. Op 17 Desember word daar samesprekinge gevoer met Kaapse Liberales van die Ballingergroep. Dit lei tot die stigting van die South African Liberal Association op 16 en 17 Januarie 1953 te Kaapstad. Alan Paton, Margaret Ballinger, dr. Oscar 
Wollheim en Leo Marquard was prominente liberales wat hierdie vergadering bygewoon het. Toe al is besluit om van die Verenigde Party weg te breek, maar ter wille van die verkiesing is dit uitgestel.

Die algemene verkiesing van 1953 het 'n verdere swaai na die Nasionale Party getoon: vir die Verenigde Party het dit 'n setelverlies van 8 beteken, vir $\operatorname{Dr} D$ F Malan 'n setelwins van 24. Die verkiesingsuitslag het die Verenigde Party gedwing om nog hegter vas te hou aan sy konserwatiewe beleid van blanke oppergesag. Hierna ontbind die United Democratic Front en die Torch Commando. Vir liberales was dit die keerpunt.

Op 9 Mei 1953 is die Liberale Party van Suid-Afrika gestig, 'n veelrassige organisasie. Bekende stigterslede was: $d r$ Oscar Wollheim, Leslie Rubin, Donald Molteno, Margaret Ballinger, Ellen Hellman, Peter Brown, Arthur Keppel-Jones, H Selby Msimang, Leo Marquard, Alan Paton, en Marion Friedman.

Die ideale wat die Liberale Party in hierdie vroeë stadium voorgestaan het, was niks meer nie as 'n blote verlengstuk van dié van die ou Kaapse Liberales. Die party het hom op die volgende beginsels gestel: die erkenning van die waardigheid van elke mens, ongeag sy ras, kleur of herkoms, asook die handhawing van fundamentele menseregte, die reg van elke mens om ten volle, maar in samehang met die regte van andere, te kan ontwikkel, die behoud van die „rule of law”, dat geen persoon op grond van ras, kleur, of herkoms, van deelname aan die regering of ander demokratiese instellings uitgesluit mag word nie; en dat politieke regte, gebaseer op 'n algemene stemlys, tot alle persone wat voldoende kwalifiseer, uitgebrei word (Robertson, $1971 \mathrm{p} \mathrm{112)}$. Vanselfsprekend sou hierdie organisasie hom stel op die basis van veelrassige sport.

Hoewel die toentertydse Liberale Party en die verbanne Kommunistiese Party diep van mekaar verskil het, het hulle tog een ideaal gemeen gehad, naamlik hul strewe na die totstandbrenging van 'n uiteindelike veelrassige maatskappy. Hulle het egter verskil oor hoe hierdie oogmerk bereik moes word: kommuniste was voorstanders van radikaliteit en revolusie, liberales het geglo aan konstitusionele metodes, aan die krag van oorreding, logika en lojale konfrontasie; waar kommuniste aangedring het op 'n totaal veelrassige gemeenskap, het liberales hul veelrassigheid gekwalifiseer met 'n gestelde beskawingsstandaard op die leuse van die ou Kaapse Liberales. 'n Mate van blanke paternalisme word dus gekontinueer. In sy stigtingsakte het 
die Liberale Party hom gedistansieer van alle vorms van totalitarisme, byvoorbeeld die kommunisme en die fascisme.

Soos die geval met die South African Liberal Group van 1952, het liberales skepties teenoor die aksies van die $\mathrm{ANC}^{\mathbf{1}}$ ), die SAIC, en veral die Congress of Democrats. So het die Liberale Party in 1953 die ANC se voorkeur aan passiewe weerstand, stakings en boikotte as onkonstitusioneel verwerp. Dit, tesame met duidelike aksente van paternalisme, het die Liberale Party onaanvaarbaar gemaak vir Albert Luthuli se ANC. Verdere verwydering kom op 26 Januarie 1955 toe die Liberale Party weier om steun te gee aan die Congress Alliance ${ }^{2)}$ se poging om op 26 Junie 'n nie-blanke Volkskongres te Kliptown te hou. Liberales het inges.en dat hierdie kongres vooraf deur kommuniste uit die Congress of Democrats tot in die fynste besonderhede uitgespel was (Robertson, 1971, p. 161) en dat die groot massa swartmense weinig aandeel in die saak gehad het.

Die Vryheidsmanifes wat op hierdie monstervergadering aanvaar is, is aan liberales voorgehou as 'n waarborg vir veelrassigheid, die kulminering van liberale beginsels. Liberales wou glad nie hieraan byt nie; die gesagstuktuur wat deur hierdie Manifes voorgestaan is, het té duidelik sosialistiese beklemtoninge bevat. Die Vryheidsmanifes het egter duidelike liberale aansprake neergelê insake die reg op vryetyd, sport en ontspanning, formuleringe wat direk aansluit by dié van die Universele Deklarasie van Fundamentele Menseregte soos in 1948 deur die VVO geformuleer.

Teen 1955 het dit tot liberales deurgedring dat die sport 'n maagdelike kwesbaarheid besit om daarmee apartheid aan die strot beet te kry. So publiseer Patrick Duncan en eerw. Trevor Huddleston op 1 Junie 1955 'n brief in die London Times waarin aangedring word op beëindiging van Suid-Afrika se deelname aan die Statebondspele tensy veelrassigheid in sport toegepas word. Dieselfde jaar word die Committee for International Recognition in Durban gestig, wat sou ywer vir die internasionale affiliasie van veelrassige nasionale sportliggame. Veelrassige sportliggame soos die Suid-Afrikaanse Tafeltennis Raad en die Suid-Afrikaanse Sokker Federasie onderskeidelik was reeds geruime tyd al besig om die affiliasiebevoegdheid van die blankbeheerde moederliggame te betwis. Liberales het hul vernuf en insigte by hierdie groep ingegooi. In Junie 1956 word die blankbeheerde Suid-Afrikaanse-Unie geskors en verkry die veelrassige SuidAfrikaanse Tafeltennis-Raad volle internasionale status; blankbeheerde sokker kry teenspoed; Suid-Afrika se blanke deelname aan die Olimpiese Spele kom in die spervuur; vader Trevor Huddleston se 
boek Naught for Your Comfort verskyn op 'n gretige internasionale mark - momentum teen apartheidsport word dus ontketen. Eerwaarde Huddleston bepleit openlike boikotte teen alle vorme van apartheidsport. Isoleer apartheidsport, en dwing hom tot oorgawe, is die kruks van sy argument.

Binne Suid-Afrika self het aansprake op veelrassige sport toegeneem. Op 26 Junie 1956, presies 'n jaar na die Kliptownse Volkskongres, verskyn $\mathrm{dr}$ T E Dönges, Minister van Binnelandse Sake, se eerste amptelike sportverklaring(Die Burger, 26656 ). Vir die eerste keer in die geskiedenis het die amptelike Regering hom verbind aan 'n duidelik omlynde sportbeleid. Kortliks het hierdie verklaring neergelê dat nie-blanke sportliggame op nasionale vlak by die blanke moederliggaam moet affilieer; dat geen veelrassige sport binne SuidAfrika toegelaat sal word nie; dat geen veelrassige spanne uit of na of binne Suid-Afrika aanvaarbaar sal wees nie; dat toeskouersgeriewe vir sportbyeenkomste afsonderlik moet wees, en dat blankes en nieblankes hul onderskeie sportsoorte afsonderlik moet beoefen en administreer, dit wil sê Blankes apart, Kleurlinge apart, Bantoes apart, en Asiate apart. Die minister het duidelik gestel dat die Regering voortaan geen visums of paspoorte sal toestaan aan persone -of spanne wat veelrassige sport op Suid-Afrika wil afdwing deur blanke SuidAfrika uit internasionale sport te forseer nie. Hiermee is 'n amptelike stempel aan apartheidsport gegee. Hierdie sportverklaring het van krag gebly totdat Min. John Vorster enkele aspekte daarvan in 1957 gewysig het.

Die sport het hom plotseling in die kryt van politieke binnegevegte bevind. Vir opportunistiese en strategiebewuste liberaliste was dit die lankverwagte pistoolskoot om op hierdie front aan te val. Die 1956-sportverklaring, met alle konskewensies wat daaruit vloei, het die skyf van aanval geword.

Om terug te keer tot die geskiedenis van die Liberale Party - waarkommuniste te alle tye bereid was om met nie-blankes op 'n basis van gelykheid saam te werk, was dit nie altyd die geval met liberaliste nie. Die indruk is gelaat dat nie-blankes, selfs in die besture van die Liberale Party 'n tweederanse rol te spele gehad het. Liberaliste wou nie hul lot onvoorwaardelik by die van die nie-blanke meerderheid inwerp nie. Samewerking het begin kwyn om die status quo te verander moes op 'n strategieverandering besluit word. Dit het gekom met die Hoogverraadsaak van 1956 toe 156 persone aangekla is van 'n sameswering om die staatsgesag omver te werp. Liberales se aandeel in die Treason Trial Defence Fund het op Albert Luthuli, Presi- 
dent-Generaal van die ANC, indruk gemaak. In Oktober 1958 spreek hy die Natalse provinsiale kongres van die Liberale Party toe en erken daarmee amptelik die bestaan van die Liberale Party. Samewerking tussen die Liberale Party en die AND word hierna hegter.

Dit het ' $n$ belangrike kentering vir liberalisme in Suid-Afrika ingelui. Dit was die voorspel vir radikale en revolusionere liberalisme, 'n benadering so ver uit pas met die ideale van die ou Kaapse Liberale . .... .

Met die keer van die vyftigerjare moes dit vir liberales duidelik geword het dat hulle 'n verloorsaak aan't strye was so lank hulle voortgaan om hul oogmerke langs konstitusionele weg te soek. Toe dit blyk dat die Liberale Party hul voelers uitsteek na die ANC, die SAIC, die SA Coloured People's Organization, en les bes, die Pan-Africanist Congress, het blanke kiesers die party finaal verwerp. Toenadering tot die nie-blankes was die enigste alternatief.

\section{RADIKALE LIBERALISME: 1958 TOT 1967}

In November 1956 volg Sir De Villiers Graaf vir advokaat J G N Strauss op as leier van aie Verenigde Party. Op daardie stadium was daar 'n aantal volksraadslede wat aansienlik liberaal oor die kleurkwessie gevoel het. Die 1958-verkiesing het vir die soveelste keer bevestig dat 'n blanke opposisie wat. aspireer om die alternatiewe regering te vorm, beslis nie die luukse van ekstreme liberale denke kan bekostig nie. Progressief denkendes binne die Verenigde Party het die keuse gehad om ò na die Liberale Party oor te stap, of om met 'n nuwe party te begin. Laasgenoemde weg is verkies.

In Augustus 1959 breek 'n groep progressiewes weg. Nege volksraadslede bedank uit die Verenigde Party en in November word die Progressiewe Party gestig, weer eens 'n verlengstuk van die ideale van ou Kaapse Liberalisme. Progressiewes, hoewel gering in getal, was oortuig dat hulle die sleutel hou vir Suid-Afrika se toekomspolitiek. Die Johannesburgse Star (16.11.'59) maak hierdie opmerking: „Not in their wildest imagination can the Progressives expect to gain power in normal conditions within the foreseeable future. But they should act as a leaver to vitalize the thinking and action of this and coming generations in a world of dynamic change."

Vir liberaal en progressief denkende blankes het die Progressiewe Party 'n tuiste gebied. Dit het oor politieke leiers van beproefde statuur beskik, onder andere Herman Steytler, Ernest Oppenheimer, 
Helen Suzman, asook Henry Lawrence, eertydse minister in die Smuts-kabinet. Gematigdes uit die Liberale Party en linkses uit die Verenigde Party het hier 'n heenkome gevind. Die Progressiewe Party het tussen die Verenigde Party en die Liberale Party in beweeg sodat laasgenoemde Party inderdaad vir die blanke kieser oorbodig geword het. Die Liberale Party moes dus of terugswenk na groter konserwatisme, of dit moes neig na groter radikaliteit. Blanke kiesers het die Liberale Party reeds oortuigend verwerp; daarom was 'n swaai na groter radikaliteit, nader aan die aspirasies van die swartman, die enigste logiese uitweg. Dit vind in 1958 plaas.

In Desember 1958 word die tweede All-African People's Conference in Akkra gehou. Die eerste konferensie is in April 1958 deur president Kwama Nkrumah van Ghana saamgeroep en word allerweë aanvaar as die eindpunt van kolonialisme in Afrika aangesien dit die eerste keer was dat staatshoofde van onafhanklike swart Afrika-lande op Afrika-bodem vergader.

Die Desember-konferensie is bygewoon deur leiers uit „koloniale" gebiede in Afrika. Die doel van die vergadering was om metodes te vind waarvolgens die vrywording van hierdie lande bewerkstellig kon word. Die Liberale Party het drie afgevaardigdes gestuur, te wete Jordan Ngubane ${ }^{3)}$ as leier, Patrick Duncan, en Cynthia Duncan. Hierdie groep het onder die indruk gekom van die erns en dwingendheid waarmee Afrika volle politieke en sosiale emansipasie van die swartman oor heel Afrika opgeëis het. Dit het spoedig geblyk dat die resep van die ou Kaapse Liberales vir die nuwe Afrika totaal onaanvaarbaar geword het. Voogdyskap en paternalisme het vloekwoorde geword, ' $n$ belediging vir die selfrespek van die swartman. Die boodskap wat hierdie afvaardiging na Suid-Afrika teruggebring het, was een van radikaliteit en absolute veelrassigheid. Sport sou hier geen uitsondering wees nie.

In 1959 beweeg die Liberale Party verder in die rigting van radikaliteit. Toe die veelrassige Pan Africanist Congress van Nelson Mandela in 1959 gestig is, was Patrick Duncan die eerste blanke wat by hierdie revolusionêre organisasie aangesluit het. Weliswaar het die Liberale Party as sodanig hom nie met die doelstellinge van die PAC vereenselwig nie, maar die feit dat van sy lede daaraan behoort het, het hom ontvanklik gemaak vir invloede vanuit hierdie en ander organisasies.

Met die uitgang van die vyftigerjare moes die Liberale Party hom in 'n situasie -van kwellende frustrasie bevind het. Soveel van sy motiewe is summier deur die Strydom- en.Verwoerd-regering gedwars- 
boom as strydend met die oogmerke van die regering. Uit hierdie frustrasie het 'n groter aggressiwiteit na vore gekom, 'n geneigdheid tot radikaliteit en ekstremisme. Metodes soos passiewe weerstand en boikotte het aanvaarbaar begin word, solank apartheid daarmee vernietig kon word. In 1958 reik Peter Brown en Alan Paton, onderskeidelik voorsitter en onder-voorsitter van die Liberale Party, 'n verklaring uit waarin aangedring word op oorsese handelsboikotte teen Suid-Afrika. Binne 'n vrye kapitalistiese sisteem bestaan daar groot ruimte vir ekonomiese manipulasies, met die gevolg dat hierdie handelsboikotte 'n geringe effek gehad het; inteendeel, dit het die weerbaarheid van die Suid-Afrikaanse ekonomie op die duur verhoog. Die aanslag is nou ten volle na sport verskuiwe. Hoe kon die sport hom verweer?

Om die effektiwiteit van die aanslag teen apartheidsport te verhoog, was dit nodig om aksies vanuit verskeie drukgroepe te koördineer. So word in die loop van 1958 die South Africar. Sports Association (SASA) in aansyn geroep om as plaasvervanger te dien vir die impotent geworde Committee for International Recognition wat in 1956 gestig is. As oorkoepelende liggaam vir veelrassige sport, het SASA hom openlik verset teen alle vorms van apartheidsport.

Verskeie liberales het hul steun aan SASA toegesê. So was Alan Paton, ondervoorsitter van die Liberale Party, die beskermheer. Dennis Brutus was die sekretaris. Afgesien van strategiebeplanning het liberales 'n morele ankerpunt vir SASA en sy aksies geword. Liberales het SASA se saak op openbare platforms met logika en passie verdedig, hier sowel as oorsee. Liberales soos Walter en Adelaine Hain, Patrick Duncan, Frederick John Harris en andere, sou spoedig hul aktiewe en morele steun gee. Dit was onvermydelik dat die Liberale Party as sodanig met sportboikotte geassosieer sou word. Toe die South African Non-Racial Olympic Committee (SAN-ROC) in Oktober 1962 gestig is om die lidmaatskap van die blankbeheerde Suid-Afrikaanse Olimpiese Vereniging by die Internasionale Olimpiese Komitee te betwis, was Alan Paton ook hier die beskermheer en Dennis Brutus die sekretaris. Dennis Brutus is later as 'n kommunis gelys.

Selde in die geskiedenis het Suid-Afrika 'n hewiger aanslag uit die liberale kamp belewe as juis gedurende die eerste helfte van die sestigerjare.

In 1960 en 1961 ontvang ' $n$ aantal radikale liberales inperkingsbevele omdat hul woorde en dade so revolusie-belade was dat hulle 'n bedreiging vir wet en orde geword het. 'n Aantal liberales raak in 1961 
betrek by versetbewegings in die Transkei en daar word drasties opgetree teen Patrick Duncan, Randolph Vigne, en Hammington Majija.

In Desember 1961 stig blanke liberales die African Resistance Movement (ARM), glo sonder die medewete van hul partyleiers. Die verklaarde oogmerke van die ARM was: ,inconvenience and confuse, disrupt and distroy". Hul dade van sabotasie was gemik teen openbare installasies wat instrumenteel was vir die instandhouding van belangrike dienste.

Die Liberale Party wat kragtens sy stigtingsakte 'n pleitbesorger van van die „rule of law" was, het nou die vernietiger daarvan geword. Weliswaar het lede soos Alan Paton, Margaret Ballinger, Leo Marquard, Jack Unterhalter en dr. Edgar Brooks 'n stabiliserende invloed op die party gehad, maar dit kon nie verhoed dat die party deur jong radikales op sleeptou geneem word nie. Vir die party self was dit ' $n$ lewensgevaarlike situasie. Die regering wat verantwoordelik gehou word vir die handhawing van wet en orde het dit moeilik begin vind om ' $n$ onderskeid te trek tussen die pogings van radikale liberales en dié van revolusionêre kommuniste. 'n Drastiese botsing het onafwendbaar geword.

John Harris, Hugh Levin, en Ronald Mutch was drie liberales met sentimente by die ARM. Harris was op daardie stadium die voorsitter van SAN-ROC. Hy was 'n bekende lid van die Liberale Party van Transvaal, asook ' $n$ intieme huisvriend van Walter en Adelain Hain, laasgenoemdes onderskeidelik die voorsitter en sekretaresse van die Liberale Partytak in Pretoria. Op 24 Julie 1964 plant John Harris koelbloedig 'n tydbom op die Johannesburgse stasie. Die ontploffing lei tot die dood van die 77 jarige mev. Ethel Rhys en die verwonding van talle omstanders, sommige permanent. Harris is skuldig bevind aan sabotasie en moord. Op 1 April 1965 word hy in Pretoria gehang. Die 15-jarige Peter Hain, seun van Walter en Adelain, het onder druk van sy ouers die begrafnisrede by die krematorium gelei. Dieselfde jong Hain sou vanaf 1969 die leidende figuur word om militante en haatgeïnspireerde boikotte teen Suid-Afrika se sport vanuit London te reël.

In sy presidensiële rede voor die kongres van die Liberale Party in Oktober 1964 het Alan Paton hom soos volg teen dade van sabotasie, geweld en agressie uitgespreek: „Any person who while a memher of the Liberal Party plans against things or persons is not only guilıy of an offense against the law, he is also guilty of grave disloyalty to the Party" (Contact, 23.10'64). Maar dit was te laat. Die party self was nie meer in staat om die wilde revolusionêre drif van sy lede in toom te hou nie. 'n Eens trotse politieke party het gedegradeer tot 'n gefrustreerde versetbeweging wat 'n bedreiging geword het vir wet en 
orde, juis dit wat hulle in prinsipe wou voorkom. Dit het geword 'n organisasie wat rasseverhoudinge vertroebel het, presies die teendeel waarna dit aanvanklik gestrewe het.

Blankes het die Liberale Party in die allerduidelikste terme verwerp; nie-blankes weer het onder die indruk gekom van hoe ver blankes werklik bereid was om te gaan ten einde te bewys dat hulle dit erns meen met wat hulle verkondig. Die ironie van die gebeure lê daarin dat op die stadium toe liberales daarin geslaag het om die vertroue van die nie-blanke te wen, hulle hul sodanig van die blanke vervreem het dat hul bestaan as politieke organisasie ongewens en selfs landsvaarlik geword het.

Verskeie lede van die Liberale Party is vanweë hul radikale politieke aksies ingeperk: Peter Hjul, die Kaapse voorsitter van die Liberale Party asook redakteur van Contact in Februarie 1963; Randolph Vigne, die nasionale waarnemende voorsitter in Februarie 1963; Jordan Ngubane, die nasionale onder-voorsitter in Mei 1963; Adelain Hain, sekretaresse van die Pretoria-tak van die Liberale Party, in Oktober 1963; Walter Vannet Hain, voorsitter van die Pretoria-tak in September 1964, Patrick Duncan, lid van die Nasionale Uitvoerende Bestuur in Maart 1961. Frederick John Harris lid van die Transvaalse Provinsiale Komitee in Februarie 1964; Peter Brown, nasionale voorsitter van die Liberale Party in Julie 1964 en weer in 1966; Selby Msimang, nasionale waarnemende voorsitter in Maart 1965. Alan Paton, geruime tyd die nasionale voorsitter, is nooit ingeperk nie. Teen die middel van die sestigerjare moes dit vir die Liberale Party duidelik geword het dat die blanke kieserskorps hulle soos 'n turksvy laat val het. Deur hul radikaliteit het hulle so ver afgewyk van die ideale van die ou Kaapse Liberales dat 'n kompromie tussen hierdie twee strominge nie meer moontlik was nie. Sterk liberale leiers soos Harry Oppenheimer en Helen Suzman het hulle totaal gedistansieer van hierdie mense. Die Progressiewe Party met sy oop liberale inslag het die verlengstuk van die Kaapse Liberale gedagte geword.

Radikale liberales wat nie bereid was om die afloop van hul dade manmoedig in die gesig te staar nie, het verkies om met eenrigtingpaspoorte die land te verlaat om vanaf veilige buitelandse platforms hul vendetta teen apartheid en apartheidsport voort te sit. Op andere is subtiele druk uitgeoefen om te skoert. Onder die uitgewekenes tel Patrick Duncan, Walter Hain, Adelain Hain, Peter Hain, Dennis Brutus, Wilfred Brutus, Chris de Broglioen Reg Hlongwane, om slegs enkeles te noem wat intiem met sportboikotaksies gemoeid was. 
Talle swart mense is met skamele hoop agtergelaat om agterna die gelag te betaal terwyl die instigeerders hoog en droog in die buiteland sit. Dat die beeld van liberalisme hiermee 'n ernstige knou toegedien is, is nie aan te twyfel nie. Onder talle blankes, veral onder Afrikaans taliges, het „liberalisme" 'n skeletiket geword. Die teenreaksie was so sterk dat wesenseie liberale momente van ons eie demokrasie agterdogtig beloer word wanneer dit op rasseverhoudinge toegepas is. Die feit dat radikale liberaliste onbeskroomd met agitators, revolusiestigters en kommuniste saamgewerk het, so lank apartheid vernietig kon word, het aan liberalisme hier in Suid-Afrika 'n kommunistiese bysmaak gegee. Die stereotiepe opvatting heers tans nog dat liberalisme die wegbereider van kommunisme is, iets so totaal botsend met die ideale van ou Kaapse Liberales soos voortgesit in die huidige kapalisties gesinde Progressiewe Party.

Die Liberale Party is uiteindelik vanweë sy revolusionêre neiginge in die ban gedoen. Op een terrein was hul sukses onbetwisbaar: die aanhits van sportboikotte teen Suid-Afrika. Suid-Afrika se blankbeheerde tafeltennis is in 1956 al skaakmat geplaas; Suid-Afrika se tradisionele sokkerbande kom vanaf 1955 in die spervuur en kry in 1961 en 1964 ernstige teenspoed by die internasionale liggaam; die All Blacktoer van 1960 na Suid-Afrika is in Nieu-Seeland voorafgegaan deur tergende betogings en versetkampanjes wat deur studente, kerke en vakbonde georganiseer is (kyk Scholtz, 1973a); deelname aan die prestigeryke Olimpiese Spele word vanaf 1964 opgeskort; die All Blacktoer van 1967 loop hom in Spetember 1965 op Loskopdam te pletter (sien Scholtz 1973b); tennis kry in die Davisbeker-wedstryde ernstige teenspoed; die Britse MCC-kriekettoer word in 1969 vanweë die D'Oliveirakwessie afgelas; in 1969 organiseer Peter Hain en sy groep Jong Liberales, bygestaan deur Dennis Brutus se San-Roc asook die Londonse Anti-Apartheid Movement, die grootste terroriste kampanje teen die toerende Springbok-rugbyspan wat nog in Brittanje aanskou is (kyk Viviers, 1970 Hain 1971); die 1970 Springbokkriekettoer deur Brittanje word uiteindelik afgelas toe terrorisme en betogings die voorland blyk te wees. So kan mens met hierdie dodemars van Suid-Afrika se internasionale sportverhoudinge aangaan. Keer op keer sal jy vind hoe dat radikale liberales, bygestaan deur sosialiste, kommuniste, Afrikane en andere bygedra het om die wurggreep teen alles wat met apartheidsport te doene het, steeds vaster te trek. Wat mense soos Duncan en Huddleston in 1955 as toekomsvisies gesien het, het teen 1967 naaste werklikheid geword: die isolasie van apartheidsport. In hul vendetta het hul aangevoer dat Suid-Afrika die skuldige party is wat politiek en sport meng; hul eie 
oogmerke was suiwer politieke gerig. Geeneen van hierdie sport-politieke kampvegters het met hul voete in sportorganisasie gestaan nie. Vir hulle het dit gegaan om politiek, selfs al moet die sport gekasty word.

Bekyk mens al hierdie politieke aksies agterna, en die intieme betrokkenheid van sport daarby, gee dit enigermate ' $n$ insig in waarom die Verwoerd-regering so ' $n$ onversetlike houding ingeneem het om alle vorms van gemengde sport summier plat te druk. Militante liberale groepe met hul obsessie om apartheid te vernietig, veral in sport, het die handhawers van die bestaande orde tot sulke polarisasie gedryf, dat aanpassings op daardie stadium net nie moontlik was sonder dat dit as swakheid uitgebuit sou word nie. Verder, as daar wel aanpassings gedoen moes word, dan moes dit kom vanuit 'n posisie van krag en eie oortuiging, was die klaarblyklike standpunt.

Gebeure soos dié op Sharpville in 1960 , die dade van sabotasie en moord in die vroeë sestigs, Rivonia in 1964, die stasiebomaanslag in 1964, San-Roc se tergende aksies, gevalle van broeiende en aggressie en les bes, die hardkoppigheid, het die spanning tussen partye sodanig aangeblaas dat kompromieë in sportverhoudinge net nie moontlik was nie, selfs al moes sport 'n dure prys betaal. Sport is nie so belangrik nie! Die voortbestaan van apartheid is belangriker as toegewings in sport. So verklaar Senator Jan de Klerk op 10 Junie 1962 te Klerksdorp: hy sal liefs wil hê dat Suid-Afrika in die sport geboikot word as dat ' $n$ duim meegegee word in die beleid van die Nasionale Party. Enige toegewing sal beteken die begin van die einde van die blanke beskawing in Suia-Afrika. (Rand Daily Mail 11.6.'62). Die beleid van apartheid moes gehandhaaf word, wat ookal die prys, Revolusionêre magte moes skaakmat geplaas of vernietig word. Dit was die taak van 'n ferme Minister van Justisie, Advokaat John Vorster. Teen 1967 is so 'n skaakmatposisie binnelands bereik en het dit dwingend tyd geword vir ' $n$ revaluering van 'n reeds benarde situasie waarin die sport hom bevind het. Die verklarings van Premier John Vorster (sien Hansard, 11 en 12 April 1967 en 19 tot 23 April 1971) het 'n nuwe era van hervorming en aanpassing in sportverhoudinge ingelui. Maar dit was op 'n stadium toe die skip al gevaarlik aan't sinke was en dit uiters moeilik sou wees om verlore inisiatief in internasionale sport terug te win.

Op hierdie stadium moet dit duidelik wees welke prominente aandeel radikale liberaliste gehad het om sportboikotte op apartheidsport af te dwing. Tog sou dit 'n oorskatting wees om die Liberale Party en sy meelopers alléén aandadig te hou vir geslaagde boikotaksies teen ons 
sport. Daar was ander drukgroepe wat eweneens kardinale bydraes gelewer het (kyk Scholtz, 1974abc). Soos in enige konflik die geval is, is daar meer as een party by die saak betrokke. Dit sou onwys wees om die skuld vir eie mislukkings alleen op die skouers van andere, in hierdie geval die liberaliste te plaas. Die versoeking is groot om steeds die blaam op ander te lê en self die rol van 'n reine engel te vertolk. Ons het op daardie punt gekom waar onbevange na eie mislukkig gekyk moet word. Dit moet ontleed en, waar nodig, hervorm, word, langs die weg wat ons Christelike sin vir reg en geregtigheid dikteer. Hierop word vervolgens kortliks ingegaan. Vir 'n vollediger beginselstandpunt, kyk Scholtz (1970b).

\section{KOERS IN VERHOUDINGE VORENTOE.}

Omstandighede dwing ons om die sportkwessie opnuut in oënskou te neem en vanuit eie oortuigings antwoorde te vind vir die dilemma - waarin ons ons bevind. Dit vra reformering vanuit die bestaande orde, nie stelselvernietiging soos radikale liberaliste eis nie. Om sigself te handhaaf moet die stelsel van veelvolkige ontwikkeling soepel genoeg wees om by veranderende eise aan te pas en te vernuwe waar nodig, selfs van koers te verander as dit die beswil van Suid-Afrika se mense dien. Dit moet 'n dinamies-progressiewe stelsel met voete in suiwere prinsipes bly. Dan alleen het dit 'n kans op voortbestaan en die skep van 'n beter Suid-Afrika vir die toekoms.

Ons bevind ons tans in 'n situasie waar die verleiding groot is om met aanpassings te kom wat die guns van die teenparty moet terugwin. Dit kan nie. Radikale liberaliste vra die algehele vernietiging van die stelsel van veelvolkige ontwikkeling (apartheid), nie aanpassing of reformering nie. Aanpassings wat van buite beheer en afgedwing word, kan net nie op die duur bevredig nie. Dit hou ernstige risiko's in, dit is kwetsend vir selfrespek en selfvertroue en erodeer boonop die beginsels waarin ons glo. As daar gereformeer moet word, en ek dink die tyd is ryp daarvoor, dan moet dit gestu word deur ons Calvinisties-demokratiese erfenis aangaande vryheid. geregtigheid, reg, orde, naasteliefde, verantwoordelikheid en realisme. Aan die een kant dikteer die beginsel, aan die ander kant is daar die praktyk met sy ingeboude beperkinge en voorskrifte. Op die duur moet die beginsels die praktyk rig, ook in ons sportverhoudinge.

Al dadelik vra mens na die juiste verhouding tussen sport en politiek. Sport as sodanig word gebind deur die konvensie om sig nie met politiek te bemoei nie, om dus soewerein in eie reg te staan. Sport moet ter wille van die sport beoefen en georganiseer word,' ter wille van die 
intrinsieke waardes wat in die sport-opgesluit lê. Ook mag politici nie die sport gebruik om daarmee eksklusiewe politieke oogmerke te bevorder nie. Hoewel dit die ideaal is dat politiek en sport so ver moontlik onafhanklik van mekaar moet staan, leer die praktyk dat daar tog ' $n$ onderlinge verbondenheid, 'n onderlmge lotsbepaaldheid bestaan. Aan die een kant is daar die oproep om soewereiniteit op eie werf, aan die andt: kant word gevra om incer-afhanklikheid, om eenheid maar met erkenning van verskeidenheid en selfbeskikking.

Geen land se sport vind binne 'n politieke vakuum plaas nie, maar binne die speelruimte en atmosfeer van 'n gegewe politieke stelsel of regíme. Binne die beperkinge wat die stelsel voorskryf, moet vryhede en regte aan die sportman gewaarborg word, elk volgens eie aard. So beoefen die Amerikaanse sportman sy sport binne die vryheid en beperkinge wat die kapitalistiese demokrasie toelaat; die Russiese sportman maak aanspraak op die vryheid wat die kommunistiese stelsel neerpen; die sportman binne ' $n$ diktatuur geniet die twy felagtige vryheid wat 'n diktatuur dikteer. Die aanspraak geld dat binne ' $n$ bepaalde politieke stelsel die sportman die vryheid moet hê om aan die sport van sy keuse deel te neem sonder dat oorweginge soos ras, kleur, geloof, herkoms, of politieke vnorkeure hom daarvan mag weerhou. Dit is die reg van die sportman. Indien lande dit skend, behou die internasionale sportgemeeskap hom die reg voor om sanksies teen so 'n land toe te pas tot tyd en wyl hy sy sake hiermee in lyn bring. Suid-Afrika staan tans in die beskuldigingsbank en daar word aangevoer dat apartheidsport ' $n$ inbreuk op hierdie reg maak. Daar word gestel dat aparhteidsport die witman bevoordeel, dat dit die swartman in sy eer en menswaardigheid krenk, en daarom verwerplik is. Dit is 'n uiters ernstige aanklag, wat ons tot eerlike selfondersoek moet dwing, selfs teen ons sin in. As hierdie aanklag waar moet wees, is hervorming nodig.

Hoe moet ons die huidige situasie in Suid-Afrika beoordeel? Moet ons dit neem soos ons dit tans vind volgens die de facto gegewenheid dus, of moet ons dit sien as in transito, as 'n epog in 'n evolusieproses op weg na ' $n$ bedeling waar normale en vreedsame mense- en volkereverhoudings in die sport in die vooruitsig gestel word? Dat ons op pad is daarheen en dat die sport 'n unieke bydrae te lewer het sodat beslag aan hierdie ideaal gegee kan word? So moet die huidige situasie ges.en word. Daar word gewerk in die rigting van soewereine vaderlande vir Suid-Afrika se swart volkeregroepe. Maar ons is nog nie daar nie; ons verkeer nog in die interimstadium, en vir hierdie 
epog moet ons 'n sportbeleid vind wat minstens billik en realisties is. Wat staan ons te doen?

Ek sien die huidige veelvolkige sportverhoudinge as ' $n$ skakel in ' $n$ lang proses wat lei na oper en vryer kontak tussen volkere en hul individue, waar geleer sal moet word om te midde van groter kommunikasie en blootstelling, eiegoed soos 'n kosbare kleinood te koester. Wanneer mens jou afvra wat tans gedoen moet word, moet die strategie van die tyd en affiniteite van die ganse Suid-Afrikaanse gemeenskap in aanmerking geneem word, wat tans kan en nie kan nie. Die doel moet wees om goeie gesindheid te bevorder op die basis van Christelike regverdigheid. Maar ook in jou nastreef van ideale moet jy jou sin vir die werklikheid behou. As sportkontak tussen rasse na konflik en agressie-lei, word daar beslis nie gebou aan goeie gesindheid en beter rassevehoudinge nie. Dit maak algeheel gemengde sport op hierdie stadium nie verkeerd nie, maar 'n uiters gevaarlike risiko. Vir die huidige lyk die volgende aanpassings in ons sportverhoudinge gewens.

$\phi \quad$ Suid-Afrikaanse spanne moet so ver moontlik suiwer op meriete gekies word.

$\phi \quad$ Alle sportmanne wat aan 'n gestelde standaard voldoen, ongeag hul ras of kleur, moet geregtig wees op Suid-Afrika se hoogste louere, sy kleure.

$\phi \quad$ Nasionale kampioenskappe en internasionale byeenkomste behoort oop te wees vir deelnemers uit alle rasgroepe.

$\phi \quad$ Waar beter verhoudinge bevorder kan word, behoort vorme van gemengde sport op klub- en provinsiale vlak toegelaat te word.

$\phi \quad$ Nie-blanke sportadministrateurs moet hul regmatige aandeel kry in die administrasie en beheer van nasionale liggame wat met internasionale liggame skakel.

Bogenoemde aanpassings kan gedoen word binne die gees van veelvolkigheid. In wese bly dit egter ' $n$ tussentydse reëling wat moet verander wanneer volkere onafhanklik word. Lede van sulke lande se aansprake op insluiting in Suid-Afrikaanse spanne verval dan. Hieroor moet vooraf duidelikheid bestaan.

Die belangrikste vraag waarmee ons ons tans moet besig hou, is nie meer of vorme van gemengde sport, noem dit veelvolkige deelname reg. of verkeerd is nie, maar hoe sulke kontak gereël moet word ten einde goeie verhoudinge te bestendig. Sport wat uitloop op konflik en agressie skaad meer as wat dit goed doen.

G. J. L. SCHOLTZ 
1) Anthony Sampson gee soos volg uitdrukking aan liberales se afkeur vir die ANC:

"There were reasons enough for the Liberals, who were generally people with ideals an integrity, to shun Congress. Like every worker's movement it had many obvious faults. Its demand for a universal franchise was alarming to anyone who had watched a beer-hall mob; its speeches, particularly of foreign affairs, smacked of crude Communist dogma; its sensitivity and lack of confidence inclined in to high-handedness with critics; its members included extreme mationalists, opportunists and Communists - undesirable bedfollows for respectable European liberals. But Congress was the representative of the African people: to avoid it was the problem of the country". (Robertson, p 167).

2) Die Congress Alliance is op 21 Maart 1954 saamgeroep as 'n organisasie wat bedoel was om gemeenskaplike aktiwiteite van die ANC, die SAIC, die SA Coloured People's Organization, die SA Congress of Trade Unions en die Congress of Democrats te koördineer.

3) Jordan Ngubane was in 1944 saam met Walter Sisulu en Oliver Tambo van die stigterslede van die ANC se Youth League.

\section{LITERATUUR}

Brooks E H APARTHEID A DOCUMENTARY STUDY OF MODERN SOUTH AFRICA London Routledge and Kagan 1968

De Klerk W J The South African and the contemporary world - SOUTH AFRICA INTERNATIONAL 1971

De Villiers H H M RIVIONIA OPERATIONS MAYIBUYE Johannesburg AfriKaanse Pero-Boekhandel 1964

Draper M S SPORT AND RACE IN SOUTH AFRICA Johannesburg South African Institute for Race Relations 1973

Hain P DON'T PLAY WITH APARTHEID London Allyn and Unwin 1971

Hellman $\mathrm{E}$ and Abrahams L HANDBOOK ON RACE RELATIONS IN SOUTH AFRICA Cape Town Oxford University Press 1949

Hoernle R F Alfred SOUTH AFRICAN NATIVE POLICY AND THE LIBERAL SPIRIT Johannesburg Witwatersrand University Press 1945 (Samevatting van gedenklesings 1938)

Horrel M A SURVEY OF RACE RELATIONS Johannesburg South African Institute for Race Relations $1961 \quad 1962 \quad 1963 \quad 1964 \quad 1965 \quad 1966 \quad 1967 \quad 1968$ 1969197019711972 Annual reports

Horell M SOUTH AFRICA AND I'HE ULYMPIC GAMES Johannesburg South African Institute for Race Relations 1969

Huddleston T C R Zwarte vlekken op Johannesburg Utrecht Het Spectrum 1956 (Translated from NAUGHT FOR YOUR COMFORT 1956)

Huddleston T $C R$ SPORT THE ARTS AND THE COLOUR BAR IN SOUTH AFRICA London Africa Bureau 1957

Luthuli A LET MY PEOPLE GO London Collins 1962

Kuper L AN AFRICAN BOURGEOISIE RACE CLASS AND POLITIC IN SOUTH AFRICA London Yale Universaty Press 1965

Paton A THE LONG WAY London Frederick A Preager 1968

Paton A SOTUH AFRICA AND HER PEOPLE London Butterworth 1970

Robertson J LIBERALISM IN SOUTH AFRICA 1949 - 1963 Oxford Clarendon Press 1971 
Scholtz G J L TOPSPORT Potchefstroom Herald 1970 (a)

Scholtz G J L Sport en politiek WOORD EN DAAD $19709316-19$ (b)

Scholtz G J L Sport en politiek - Geskiedenis van die Maori-kwessie RAPPORT 25/11/1973 (a)

Scholtz G J L Sport en politiek - Die verlig-verkrampte stryd RAPPORT $2 / 12 / 1973$ (b)

Scholtz G J L Sport en politiek in konflik - Die geskiedenis van tafeltennis DIE TRANSVALER 15/4/1974 (a)

Scholtz G J L Sport en politiek in konflik - Die aandeel van Kommuniste in sportboikotte teen Suid-Afrika. DIE TRANSVALER 16/4/1974 (b) t

Scholtz G J L Sport en politiek in konflik - Dis historiese aanloop tot sportboikotte DIE TRANSVALER 17/4/1974 (c)

Thompsen R RACE AND SPORT London Oxford University Press 1964 Viviers G RUGBY AGTER DORINGDRAAD Johannesburg J P van der Walt en Seun 1970

Wilson $M$ and Thompson $L$ THE OXFORD HISTORY OF SOUTH AFRICA II SOUTH AFRICA 1870 - 1966 Oxford Clarendon Press 1971 